\title{
MODAL SOSIAL KELOMPOK RENTAN SEBAGAI UPAYA DISASTER RISK REDUCTION (DRR)
}

\author{
Zeni Eka Putri $\left({ }^{1}{ }^{*}\right)$, Azwar $\left({ }^{2}\right)$ \\ ${ }^{12}$ Department of Sociology, FISIP, Universitas Andalas, Padang, West Sumatra, Indonesia.
}

\section{ARTICLE INFORMATION}

$\begin{array}{ll}\text { Submitted } & : 21^{\text {st }} \text { November, } 2019 \\ \text { Review } & : 13^{\text {th }} \text { September, 2020 } \\ \text { Accepted } & : 09^{\text {th }} \text { November, 2020 } \\ \text { Published } & : 15^{\text {th }} \text { December, 2020 } \\ \text { Available Online } & : \text { December, 2020 }\end{array}$

\section{KEYWORDS}

Social Capital; DRR; vulnerable group

\section{CORRESPONDENCE}

*E-mail:zeniekaputri@soc.unand.ac.id

\begin{abstract}
A B S T R A C T
Padang City has low resilience for earthquake and tsunami disaster. Actually, social capital can be used as a strategy for overcoming impacts and efforts to reduce the level of risk disaster. According to Siegler, social capital have four aspects, there are personal relationships, social network support, civic engangement, and trust and cooperative norms. The research objectives are: 1) Describe the knowledge and experience of vulnerable groups in dealing with disasters (earthquake and tsunami); 2) Identifying vulnerable groups' social capital as a disaster risk reduction (DRR) effort; 3) Describe the opportunities and obstacles / threats in the use of social capital as an effort to disaster risk reduction (DRR). The research method is qualitative with case study. The location of this research in Pasie Nan Tigo, Koto Tangah District, Padang City. The determination of informants is a purposive sampling technique. This research has 22 informants. They criteria of informants are; 1) Have settled in red zone area for at least 5 years; 2) The distance between the house and the beach is a maximum radius of $3 \mathrm{~km}$. The results of the research are; 1) Vulnerable groups have the knowledge and experience about disasters; 2) Social groups already have social capital in 4 aspects of social capital such as personal relationships, social networking support, civic engangement, and trust and coorperative norm; 3) Social capital have opportunities and challenges from internal and external side.
\end{abstract}

\section{A. PENDAHULUAN}

ndonesia merupakan daerah yang rawan bencana alam. Aktivitas patahan dan wilayah gunung api di Indonesia memberikan resiko terhadap bencana gempa bumi dan tsunami (Amri dkk, 2016:15). Sumatera Barat merupakan salah satu provinsi yang rawan terhadap gempa bumi dan tsunami. Pada tanggal 30 September 2009 pukul 17:16:09 WIB seluruh wilayah Sumatera Barat merasakan guncangan gempa bumi yang sangat kuat. Gempa bumi dengan kekuatan $7.9 \mathrm{SR}$ dengan kedalaman $71 \mathrm{~km}$ dan pusat gempa pada $0.84 \mathrm{LS}$ - 99.65 BT ini kurang lebih sekitar $57 \mathrm{Km}$ Barat Daya Pariaman. Kota Padang merupakan salah satu kota yang mengalami dampak kerusakan parah dari gempa tersebut.

Berdasarkan Dokumen Rencana Kontingen si Tsunami Kota Padang Tahun 2013 diketahui bahwa ancaman bahaya gempa bumi dan tsunami memiliki probability dan dampak yang besar bagi Kota Padang. Probability pada level 4 madsudnya adalah bencana kemung kinan besar $(60 \%$ - $80 \%$, terjadi tahun depan, atau sekali dalam 10 tahun mendatang). Dampak pada level 4 madsudnya adalah akan berdampak parah sekitar 60\%-80 \% wilayah hancur. Sedangkan dampak pada level 5 madsudnya adalah akan berdampak sangat parah sekitar 80 $\%$ - $99 \%$, wilayah hancur dan lumpuh total.

Ancaman terhadap gempa bumi dan tsunami di Kota Padang semakin mengkha watirkan. Pada Januari 2019, Pemerintah Provinsi Sumatera Barat mengadakan kegiatan rakor mitigasi dan penanggulangan bencana. Hasil penelitian dari LIPI, diketahui bahwa salah satu kota yang berpotensi sangat tinggi terjadi gempa bumi dan tsunami di wilayah Sumbar, yakni Kota Padang, dengan potensi gempa megathrust di Kabupaten Kepulauan Mentawai berkekuatan 8.9 magnitudo.

Berdasarkan hasil penelitian Harli (2015), hasil dari menggunakan teknik overplay diketahui bahwa ada tujuh kecamatan yang kerentanan tinggi terhadap bencana (khususnya gempa bumi 
dan tsunami). Lebih lanjut disajikan pada tabel 1 berikut ini.

Tabel 1.

Kecamatan yang Memiliki Kerentanan Tinggi Bencana di Kota Padang

\begin{tabular}{|c|c|c|}
\hline No & Kecamatan & Tingkat Kerentanan \\
\hline 1 & $\begin{array}{l}\text { Bungus Teluk } \\
\text { Kabung }\end{array}$ & $\begin{array}{l}87 \% \text { termasuk kedalam zona } \\
\text { merah tsunami dan } \\
13 \% \text { zona bahaya kuning } \\
\text { tsunami }\end{array}$ \\
\hline 2 & Padang Selatan & $\begin{array}{l}100 \% \text { termasuk ke dalam zona } \\
\text { merah tsunami }\end{array}$ \\
\hline 3 & Padang Timur & $\begin{array}{l}100 \% \text { termasuk ke dalam zona } \\
\text { merah tsunami }\end{array}$ \\
\hline 4 & Padang Barat & $\begin{array}{l}100 \% \text { termasuk ke dalam zona } \\
\text { merah tsunami }\end{array}$ \\
\hline 5 & Padang Utara & $\begin{array}{l}100 \% \text { termasuk ke dalam zona } \\
\text { merah tsunami }\end{array}$ \\
\hline 6 & Nanggalo & $\begin{array}{l}100 \% \text { termasuk ke dalam zona } \\
\text { merah tsunami }\end{array}$ \\
\hline 7 & Koto Tangah & $\begin{array}{l}67 \% \text { zona merah, } 28 \% \text { zona } \\
\text { kuning dan } 5 \% \text { zona hijau }\end{array}$ \\
\hline
\end{tabular}

Dari tabel 1 diketahui bahwa ada lima kecamatan yang $100 \%$ berada pada zona merah tsunami. Sedangkan Kecamatan Bungus teluk kabung $87 \%$ daerahnya masuk ke zona merah dan Kecamatan Kota Tangah $67 \%$ wilayahnya masuk ke zona merah. Sehingga, apabila nanti terjadi bencana alam seperti gempa bumi dan tsunami sudah tentu akan membawa dampak serius. Adapun 4 Kecamatan lainnya seperti Kecamatan Pauh, Kecamatan Kuranji, Keca matan Lubuk Kilangan dan Kecamatan Lubuk Begalung wilayahnya tidak termasuk kepada zona merah tsunami.

Respon masyarakat Kota Padang terhadap bahaya tsunami khususnya terhadap akses peringatan dini tsunami, pengetahuan dan pengalaman, serta kesiapan evakuasi masih rendah. Padahal hal ini perlu diperhatikan untuk mengurangi dampak jika terjadi bencana (Anwar, 2012:53). Pengurangan resiko bencana (disaster risk reduction) perlu dilakukan agar tidak terjadi banyak korban jiwa apabila nanti bencana gempa bumi dan tsunami terjadi. Ini merupakan sebuah pendekatan sistematis untuk mengi dentifikasi, mengkaji dan mengurangi resiko bencana. Hal ini bertujuan untuk mengurangi kerentanan sosial ekonomi terhadap bencana dan menangani bahaya-bahaya lingkungan ataupun bahaya lainnya yang menimbulkan kerentanan. Pengurangan resiko bencana mengambil aspek kehati-hatian pada saat penanggulangan bencana. Yang meliputi aspek perencanaan dan penanggulangan bencana, sebelum, saat dan sesudah terjadi bencana (UNDP,2012:12).

Berdasarkan hasil penelitian Teja (2015: 17), apabila terjadi bencana, kelompok yang paling diwaspadai akan terkena dampaknya adalah kelompok rentan. Kelompok rentan dalam situasi darurat bencana memerlukan perhatian dan perlakuan khusus. Peningkatan kesadaran dan pengetahuan tentang bagaimana meng hadapi bencana, termasuk melindungi kelompok rentan perlu diupayakan dalam rangka memperkuat kesiapsiagaan masyarakat. Oleh karena itu, kelompok rentan menjadi sangat rawan menjadi korban dalam situasi bencana karena ketidakberdayaannya. Kelompok yang cenderung terkena dampak merusak yang diakibatkan ancaman bahaya bencana, khususnya bencana gempa bumi dan tsunami di Kota Padang. Contoh dari kelompok rentan tersebut adalah orang-orang yang memiliki potensi besar terkena dampak dari bencana alam khususnya gempa bumi dan tsunami. Adapun kelompok rentan tersebut adalah orangorang yang tinggal di daerah zona merah khususnya di sekitar pinggir pantai.

Perlu adanya pengetahuan, sikap, rencana tanggap darurat, dan sistem peringatan bencana gempa bumi terhadap kesiapsiagaan masyarakat terhadap bencana. Hal ini juga harus didukung oleh kesiapsiagaan pemerintah (Febriana, 2015). Di Kota Padang, pemerintah sudah melakukan sosialisasi mengenai siaga terhadap bencana dan membangun shelter. Akan tetapi, perhatian terhadap kelompok rentan masih perlu diting katkan. Berdasarkan PP Walikota Padang No 25 Tahun 2018 mengenai Prosedur Penang gulangan Bencana, dijelaskan bahwa ketahanan Kota Padang masih rendah dalam menghadapi gempa bumi dan tsunami. Hal ini dipengaruhi oleh morfologi pantai yang landai, sebaran pemukiman yang padat dan kawasan yang terbangun di kawasan pesisir dengan ketinggian $<10 \mathrm{mpl}$, serta belum tersedianya tempat-tempat dan jalur evakuasi yang memadai pada kawasan yang diidentifikasi sebagai wilayah redzone.

Penerapan kebijakan sosial yang dibuat oleh pemerintah bertujuan mensejahterakan masyarakat terkadang menghadapi kendala. Oleh karena itu, model kebijakan sosial yang dibuat oleh pemerintah mengenai kebencanaan juga tentu akan mempengaruhi kesuksesan pengurangan resiko bencana di suatu daerah di Kota Padang. Sebagai contoh penerapan model kebijakan terhadap pengurangan angka kemis kinan pada Kabupaten dan Kota di Sumatera Barat, berdasarkan hasil penelitian Azwar (2019:233), penerapan kebijakan sosial untuk pengurangan kemiskinan di Sumatera Barat tidak berjalan dengan baik dipengaruhi beberapa hal seperti masih bergantung bantuan pusat, penempatan orang dilembaga program tidak sesuai dengan kompetensi, dan perangkat lokal organisasi tidak berjalan dengan baik.

Selain upaya secara eksternal (dari pemerintah), perlu juga dilakukan identifikasi mengenai modal sosial yang dimiliki oleh kelompok rentan dalam rangka pengurangan 
resiko bencana. Hal ini diperlukan, agar meminimalisir terjadinya korban saat terjadi bencana. Berdasarkan hasil penelitian Lany Verawati (2013), modal sosial bisa dijadikan sebagai strategi alam mengatasi dampak dan upaya menurunkan tingkat resiko bencana. Hasil penelitian Tanzil dkk (2018), menyatakan bahwa modal sosial menjadi kekuatan bagi masyarakat dalam memobilisasi sumber daya untuk menghadapi bencana. Untuk itu, pola sinergi dalam penanggulangan berbasis modal sosial perlu diperkuat sehingga dalam penanganan bencana merupakan aktivitas yang saling memperkuat.Selain itu, berdasarkan hasil pene litian Tatik Yunarti (2018), kepemimpinan yang demokratis sangat dibutuhkan dalam penge lolaan modal sosial yang ada. Hal itu karena seorang pemimpin yang demokratis tersebut lebih terbuka dan dapat mendengarkan masukan dari bawahannya dan masyarakat.

Masyarakat yang tangguh adalah masya rakat yang mampu menanggulangi bencana dengan beradaptasi terhadap potensi bencana yang ada di lingkungannya serta mampu memulihkan keadaan menjadi sedia kala bahkan lebih baik bila bencana menimpa. Ketangguhan ini harus dibangun dan ditingkatkan dengan mempertimbangan kapasitas dan kemampuan yang ada di masyarakat (Sitorus, 2018:30). Diharapkan ketika masyarakat memiliki dan bisa memanfaatkan modal sosial yang dimilkinya, maka akan tercipta masyarakat yang berdaya dan tangguh bencana. Modal sosial menurut Siegler melihat empat aspek modal sosial yang lebih menyeluruh yaitu personal relationship, social network support, civic engangement, dan trust and cooperative norms. Penelitian Wanda Fitri (2014) menunjukkan bahwa nilai budaya lokal Minangkabau memiliki peran positif terhadap resiliensi dan kesiapan menghadapi bencana. Adapun nilai-nilai lokal Minangkabau seperti nilai kebersamaan (saiyo-sakato), nilai empati dan toleransi (sahino-samalu), prinsip gotong-royong (sapikue-sajinjiang).

Artikel ini bertujuan untuk mengidentifikasi modal sosial kelompok rentan sebagai upaya disaster risk reduction (DRR) di Kota Padang, dan mendeskripsikan peluang dan hambatan/ ancaman dalam pemanfaatan modal sosial sebagai upaya disaster risk reduction (DRR) di Kota Padang.

\section{B. METODE PENELITIAN}

$\mathrm{M}$ etode yang digunakan dalam penelitian ini adalah metode penelitian kualitatif. Adapun data yang dikumpulkan dan dianalisis biasanya terdiri dari dua hal yaitu katakata (lisan maupun tulisan) dan perbuatanperbuatan manusia. Dengan arti kata, dalam penelitian kualitatif tidak menganalisis angka- angka (Afrizal, 2014:13). Dalam hal ini diterapkan metode studi kasus (case study), maksudnya, Penelitian studi kasus memusatkan perhatian pada satu objek tertentu yang diangkat sebagai sebuah kasus untuk dikaji secara mendalam sehingga mampu membongkar realitas di balik fenomena.

Adapun studi kasus pada penelitian ini adalah pada Kelurahan Pasie Nan Tigo Kecamatan Koto Tangah Kota Padang. Alasan pemilihan lokasi ini adalah karena lokasi tersebut berada di zona merah, terdapat juga lokasi wisata Pantai Pasir Jambak, serta akses daerah yang agak tertutup tidak ada kendaraan umum yang melewati Kelurahan Pasie Nan Tigo, sehingga apabila terjadi bencana gempa bumi dan tsunami, sulit untuk segera mencapai daerah ketinggian. Kelurahan Pasie Nan Tigo belum memiliki shelter resmi untuk evakuasi saat terjadi bencana alam gempa bumi dan tsunami.

Kriteria dari informan penelitian ini adalah: 1) Sudah tinggal menetap di daerah penelitian (daerah zona merah) minimal 5 tahun; 2) Jarak rumah dengan pantai maksimal radius $3 \mathrm{~km}$. Informan penelitian ini berjumlah 22 orang yang terdiri dari 18 orang warga kelurahan Pasia Nan Tigo, 1 orang Aparat Kelurahan Pasia Nan Tigo, 1 orang KSB Pasia Nan Tigo, 1 orang staff Kecamatan Koto Tangah dan 1 orang BPBD Kota Padang.

Teknik Pengumpulan data adalah wa wancara mendalam, observasi dan pengumpulan dokumen. Model analisis data yang dilakukan pada penelitian ini adalah model interaktif Miles dan Huberman. Reduksi data dan penyajian data dengan memperhatikan hasil dari data yang dikumpulkan, kemudian pada proses penarikan kesimpulan dan verifikasi.

\section{HASIL DAN PEMBAHASAN}

\section{Identifikasi Modal Sosial pada Kelompok Rentan sebagai Upaya Disaster Risk Reduction (DRR) di Kota Padang}

$\mathrm{M}$ enurut Siegler dalam Motkuri 2018, based on OECD, Office for National Statistics. Terdapat 4 aspek dalam modal sosial, berikut uraiannya: (1) Personal Relationships; Aspek modal sosial ini mengacu pada "struktur dan sifat dari hubungan pribadi orang", dan berkaitan dengan siapa orang tahu dan apa yang mereka lakukan untuk membangun dan mempertahankan hubungan pribadi mereka., (2) Social Network Support; Ini merujuk pada "tingkat sumber daya atau dukungan yang dapat dilakukan seseorang menarik dari hubungan pribadi mereka", tetapi juga mencakup apa yang dilakukan untuk orang lain secara pribadi, (3) Civic Engagement (Keterlibatan Masyarakat); Ini merujuk pada 
"tindakan dan perilaku yang dapat dilihat sebagai berkontribusi positif terhadap kehidupan kolektif suatu komunitas atau masyarakat". Ini termasuk kegiatan-kegiatan seperti sukarelawan, politik partisipasi dan bentuk-bentuk aksi masyarakat lainnya. (4) Trust and Cooperative Norms; Ini mengacu pada kepercayaan dan norma kerja sama atau nilai-nilai yang membentuk cara orang berperilaku terhadap satu sama lain dan sebagai anggota masyarakat. Kepercayaan dan nilai-nilai yang bermanfaat bagi masyarakat secara keseluruhan (seperti misalnya solidaritas dan kesetaraan) dapat tentukan berapa banyak orang dalam suatu masyarakat yang mau bekerja sama satu sama lain.

Dari uraian di atas, penulis menggunakan modal sosial menurut Siegler yang melihat empat aspek modal sosial yang lebih menyeluruh yaitu personal relationship, social network support, civic engangement, dan trust and cooperative norms.

\subsection{Aspek Personal Relationship \\ a. Hubungan/interaksi dalam keluarga (nuclear familiy/extended family) bersifat asosiatif}

Nuclear family atau keluarga inti merupakan keluarga yang dibentuk dari ikatan perkawinan. Keluarga ini biasanya terdiri dari ayah, ibu dan anak-anak. Berdasarkan hasil penelitian di lapangan hubungan interaksi dalam keluarga inti bersifat asosiatif yaitu bentuk dari hubungan tersebut bersifat positif dan menghasilkan persatuan. Dalam hal ini, bentuk interaksi sosial yang terjadi adalah korporasi/kerjasama. Frekuensi interaksi bisa terjadi setiap hari. Bentuk kerjasama yang dilakukan adalah saling membantu dalam hal meminjamkan uang, saling berkirim makanan, dan saling berkunjung.

Interaksi orangtua dan anak terjadi secara langsung dan tidak langsung. Secara langsung terjadi apabila orangtua dan anak tinggal pada satu rumah, misalnya interaksi terjadi di rumah, melakukan percakapan di meja makan. Apabila anak tinggal tidak serumah dengan orangtua, interaksi langsung masih bisa terjadi, yaitu ketika anak datang berkunjung ke rumah orangtuanya. Apabila rumah anak jaraknya dekat dengan orangtua, anak bisa berkunjung setiap hari atau minimal sekali seminggu. Hal menarik lainnya yang ditemukan adalah, ada keluarga yang memang tinggal di daerah tersebut rumah berdekat-dekatan bahkan bertetangga dengan keluarga batihnya. Sehingga proses interaksi yang terjalin menjadi sering bahkan bertemu setiap hari.

Interaksi tidak langsung terjadi apabila orangtua dan anak terpisah jarak disebabkan karena tidak tinggal serumah dengan orangtua ataupun anak yang merantau. Interaksi tidak langsung biasanya menggunakan media tertentu. Salah satu media yang digunakan adalah handphone. Dalam hal ini, baik orangtua atau pun anak tetap bisa melakukan interaksi dan saling bertukar kabar. Dalam pengurangan resiko bencana, potensi mendapatkan bantuan baik secara baik secara moril ataupun materil dari keluarga inti cukup besar.

Extended family atau keluarga luas adalah keluarga besar yang merupakan gabungan dari keluarga inti beserta sanak saudara baik dari pihak ayah ataupun pihak ibu seperti kakek, nenek, sepupu, keponakan, cucu, dan lain sebagainya. Bentuk interaksi yang terjalin pada keluarga inti adalah asosiatif dan bersifat kooperatif/kerjasama. Akan tetapi, frekuensi interaksi yang terjadi tidak sebanyak nuclear family. Hal ini disebabkan oleh lokasi jarak rumah dengan keluarga luas. Ada yang jarak lokasi rumahnya berdekatan dan sering terjadi interaksi, ada juga yang jarak rumahnya berjauhan. Sehingga memungkinkan adalah berinteraksi tidak langsung menggunakan handphone.

\section{b. Hubungan/interaksi dengan teman dekat dan tetangga bersifat asosiatif dan disosiatif}

Berdasarkan hasil penelitian yang dilakukan, hubungan/ interaksi sosial dengan teman dekat tidak terlihat. Hal ini disebabkan karena kondisi dan situasi seperti teman dekat tidak tinggal berdekatan atau tidak memiliki teman dekat. Interaksi peer group tidak bersifat dekat. Berdasarkan hasil observasi di lapangan, rumah penduduk di Kelurahan Pasie Nan Tigo tergolong padat. Hal ini menyebabkan jarak rumah satu dengan yang lainnya berdekatan. Menariknya, hubungan interaksi dengan tetangga berbentuk asosiatif dan disosiatif.

Bentuk hubungan asosiatif bersifat positif dan penyatuan. Dalam hal ini bersifat koorperatif atau kerjasama. Seperti saling membantu apabila ada masalah keuangan. Akan tetapi, hubungan yang terbentuk tidak secara personal, seperti menjenguk saat sakit, takziah saat kematian. Selain itu, hubungan yang terbentuk dengan tetangga juga bersifat disosiatif, yaitu bersifat negatif dan mengarah ke arah perpecahan. Hal ini disebabkan oleh ketidak harmonisan dengan tetangga disebabkan tetangga tidak mau membantu baik secara moril atau materil apabila mengalami kesusahan. Misalnya, ada ketidakmauan meminta bantuan berupa pinjaman uang ke tetangga disebabkan apabila dilakukan hal tersebut, maka tetangga akan "menggunjingkan" si peminjam uang. Salah satu tempat untuk berinteraksi adalah lapau. Bapak-bapak biasanya akan ke lapau untuk bercengkrama dan "maota-ota". Sehingga hu 
bungan dengan tetangga bisa tetap terjalin dengan baik.

Interaksi tergantung pada cara yang digunakan oleh individu maupun kelompok dalam menyikapi berbagai fenomena yang terdapat di dalam masyarakat. Sering kali, fenomenafenomena lahir sebagai akibat pengaruh sosial budaya yang terurai berdasarkan letak geografis, etnis atau kesukuan, agama atau keyakinan maupun ciri fisik. Fenomena dapat mengarah kepada indikasi disintegrasi apabila proses interaksi masyarakat terjalin dengan buruk. Namun, juga dapat memperkuat integrasi apabila proses interaksi masyarakat berlangsung dengan baik (Purbasari, 2019:5). Dari penelitian yang dilakukan, interaksi dalam keluarga dapat memperkuat integrasi. Akan tetapi, interaksi dengan tetangga dan teman dekat ada yang memperkuat integrase dan ada yang mengarah pada disintegrasi.

\subsection{Social Network Support}

Jaringan sosial (social network) menurut Damsar adalah studi melihat hubungan antar individu yang memiliki makna subjektif yang dikaitkan/ dihubungkan dengan simpul dan ikatan. Simpul disini adalah aktor dalam jaringan dan ikatan adalah hubungan antar aktor. Ada sedikit perbedaan antara jaringan sosial dengan Social Network support/dukungan dari jaringan sosial. Social network support adalah merujuk pada "tingkat sumber daya atau dukungan yang dapat dilakukan seseorang menarik dari hubungan pribadi mereka", tetapi juga mencakup apa yang dilakukan untuk orang lain secara pribadi. Jadi, dari jaringan yang dimiliki, seperti tingkatan sumberdaya/dukungan yang dilakukan.

Berdasarkan hasil penelitian di lapangan, maka ditemukan mengenai social netwotk support yang dimiliki adalah sebagai berikut:

\section{a. Memiliki keluarga yang dapat diandalkan memberikan bantuan secara moril/materil ketika mengha dapi bencana}

Keluarga, baik itu keluarga batih (nuclear family) maupun keluarga luas (extended family) merupakan sumber utama dukungan bagi kelompok rentan. Hal ini juga dipengaruhi oleh hubungan keluarga dan kekerabatan yang dekat sehingga jaringan dan kepercayaan terbentuk. Dukungan yang diberikan dari keluarga bisa bersifat materil dan moril. Contoh, dari dukungan materil dapat berupa sesama keluarga dapat saling meminjamkan uang apabila terdesak akan kebutuhan. Selain itu, dukungan moril juga ditunjukkan seperti saling berkunjung apabila rumah keluarga masih berada dalam kota yang sama. Apabila dekat bisa saling mengunjungi setiap hari, namun apabila rumah jauh bisa saling mengunjungi sekali dua minggu atau sekali sebulan. Akan tetapi, selain itu juga bisa dilakukan komunikasi melalui alat komunikasi handphone.

Peran dari dukungan dalam pengurangan resiko bencana juga dapat dilihat pada saat terjadi bencana alam gempa bumi contohnya pada tahun 2009 lalu. Anggota keluarga yang rumahnya di pinggir pantai, mengungsi ke tempat sanak keluarga yang rumahnya berada di zona hijau. Selain itu, bagi yang tidak bersedia mengungsi atau evakuasi, sanak keluarga akan berkunjung ke tempat keluarganya yang terkena dampak gempa di Kelurahan Pasie Nan Tigo sekalian memberikan bantuan makanan, obatobatan, membersihkan rumah.

\section{b. Saling bertukar bantuan dan terlibat dalam kegiatan sosial dengan tetang ga dan lingkungan sekitar baik yang berhubungan dengan pengurangan resiko bencana ataupun tidak.}

Masyarakat di Kelurahan Pasie Nan Tigo masih terlibat aktif saling membantu baik dalam keadaan terjadi bencana maupun tidak terjadi bencana. Biasanya, dalam hal perkawinan, masyarakat sekitar akan saling membantu. Contohnya, akan datang membantu untuk memasak ke tempat baralek. Masyarakat akan siap membantu di dapur untuk memasak hidangan baralek. Sifatnya adalah sukarela. Tidak diberikan bayaran/upah untuk membantu dalam kegiatan memasak baralek tersebut. Selain itu, masyarakat juga masih aktif terlibat apabila ada kematian di kelurahan tersebut. Masyarakat akan ikut menyolatkan dan menyelenggarakan jenazah di rumah duka. Biasanya pelayat sekitar juga akan datang takziah dengan membawa beras ke rumah duka. Sifat-sifat bantuan yang diberikan masyarakat adalah bantuan moril.

Selain itu, dukungan tetangga/masyarakat sekitar juga terlihat pada saat menghadapi bencana. Sebagai contoh, pada saat terjadi gempa 2009, masyarakat saling membantu seperti membersihkan rumah korban gempa yang rusak, membantu memasang terpal, juga saling berbagi bantuan makanan. Akan tetapi, tidak ada bantuan yang sifatnya berupa uang. Jadi, dapat diketahui bahwa kerjasama dan semangat kegotongroyongan masih ditemukan di tengah masyarakat Kelurahan Pasie Nan Tigo.

\section{c. Pemerintah baik dari tingkat kelurahan, kecamatan dan kota padang mengambil peran dalam pengurangan resiko bencana akan tetapi belum maksimal.}

Pemerintah Kota Padang di bawah BPBD Kota Padang terlibat aktif dalam upaya pengurangan 
resiko bencana dalam mulai dari pemberian informasi sampai simulasi. Apalagi sudah dibentuk juga KSB (Kelompok Siaga Bencana). Akan tetapi, dalam pelaksanaan kegiatan KSB masih belum rutin. Ketika ada anggaran, baru kegiatan terlaksana. Hal ini mungkin juga dipengaruhi oleh keanggotaan yang bersifat sukarela. Kemudian, pihak kelurahan dan kecamatan lebih banyak sebagai fasilitator pemerintah Kota/pihak universitas dalam memberikan ilmu, bantuan bagi kelurahan Pasia Nan Tigo. Belum ada inisiatif murni dari pihak kelurahan dan kecamatan dalam pengurangan resiko bencana.

Kegiatan-kegiatan pengurangan resiko bencana diinisiasi oleh pemerintah khususnya BPBD Kota Padang. Kegiatan yang sudah dilakukan oleh pemerintah seperti memberikan informasi mengenai bencana khususnya bencana gempa bumi dan tsunami. Informasi yang diperoleh adalah mengenai apa saja yang harus dilakukan pada saat pasca bencana, saat bencana dan pasca bencana. Pemberian informasi dilakukan dengan sistem ceramah dan ada juga dengan penyebaran-penyebaran brosur mengenai kebencanaan. Salah satu contoh brosur yang dibagikan adalah mengenai Padang Kota Cerdas Bencana. Ini berisikan ciri-ciri gempa berpotensi tsuami, apa yang harus dilakukan saat terjadi bencana, tindakan apa yang harus dilakukan ketika gempa berpotensi tsunami. Selain itu, juga dilakukan simulasi bencana ke sekolah-sekolah dan kepada masyarakat. Salah satu contohnya adalah adalah pada saat memperingati hari kebenca naan nasional. Diadakan kegiatan sosialisasi dan simulasi di daerah yang rawan bencana.

Jaringan budaya, yaitu sistem komunikasi melalui nilai-nilai budaya dimulai dan diperkuat. Jaringan budaya merupakan suatu jaringan komunikasi informal yang merupakan saluran komunikasi primer. Fungsi utamanya yaitu untuk menyalurkan informasi dan memberi interpretasi terhadap informasi (Putri, 2018:141). Dalam pelaksanaan kegiatan pemberian informasi, BPBD sudah membentuk KSB yang anggotanya berasal dari masyarakat daerah setempat. Diharapkan dengan membentuk KSB, pemberian informasi mengenai kebencanaan bisa dilakukan secara rutin. Akan tetapi, hal ini terknedala karena kegiatan-kegiatan ini masih bergantung kepada anggaran yang diberikan.

\subsection{Civic Engangement}

- Keterlibatan aktif secara suka rela dalam kegiatan sosial dan event

Sebelumnya, di Kelurahan Pasie Nan Tigo, telah memiliki kelompok-kelompok sosial. Seperti, adanya kelompok arisan dan juga ada kelompok nelayan. Selain itu, ada juga kelompok penyu. Akan tetapi, kelompok-kelompok yang dibentuk tersebut, tidak berhubungan dengan keben canaan. Kegiatan-kegiatan yang dilakukan secara gotong royong adalah seperti saat ada event tertentu seperti 17 Agustusan. Ketika ada acara-acara yang bersifat event tersebut, maka masyarakat akan saling membantu dalam penyelenggaraan acara. Contohnya, adanya perlombaan-perlombaan dalam memperingati 17 agustusan, lomba balap karung, adanya musik orgen dan lain sebagainya. Selain itu, kegiatan gotong royong diadakan juga untuk menyambut bulan Ramadhan. Akan tetapi, kegiatan-kegiatan ini tidak berhubungan langsung dengan upaya pengurangan resiko bencana.

\section{- Dibentuknya KSB (Kelompok Siaga Bencana) yang bersifat sukarela dalam pengurangan resiko ben cana}

Belum ada kelompok kebencanaan yang sifatnya button-up, kelompok yang dibentuk benar-benar dibentuk atas kesadaran masyarakat dan berdasarkan need assessment dari masyakat itu sendiri. Kelompok bencana yang dimiliki Kelu rahan Pasie Nan Tigo adalah Kelompok Siaga Bencana (KSB) yang dibentuk oleh BPBD Kota Padang. Kelompok ini memiliki relawan KSB yang berasal dari Kelurahan Pasie Nan Tigo. KSB ini bertugas untuk memberikan informasi dalam menghadapi bencana, baik pada saat prabencana, saat bencana, maupun setelah terjadi bencana. Sudah ada kegiatan pemberian informasi tersebut dilakukan pada kelompok rentan. Keanggotaan bersifat sukarela.

Ada beberapa penyebab yang ditemukan berkaitan dengan alasan kelompok rentan tidak berpartisipasi dalam kegiatan pengurangan resiko bencana baik pada saat pemberian informasi oleh BPBD Kota Padang/KSB maupun pada saat dilakukan simulasi yaitu; 1) Tidak bisa meninggalkan pekerjaan, contohnya ketika berprofesi sebagai nelayan yang sedang melaut. Kelompok rentan tidak bisa meninggalkan pekerjaannya untuk memperoleh informasi ataupun melakukan simulasi. Selain itu, ketika kelompok rentan bekerja sebagai pedagang, maka dia memilih untuk membuka kedai/warung dibandingkan ikut kegiatan. Hal ini disebabkan oleh keadaan ekonomi yang menyebabkan harus memenuhi kebutuhan sehari-hari; 2) Kondisi fisik yang tidak memungkinkan. Khususnya bagi lansia, kegiatan pemberian informasi apalagi simulasi, yang mengharuskan berjalan dan mempraktekkan proses evakuasi tidak bisa diikuti oleh lansia. Karena kondisi fisik yang tidak memungkinkan dan mulai sakit-sakitan. Sehing ga lansia jarang yang mengikuti kegiatan tersebut. 
Dalam pelaksanaannya, kegiatan KSB ini memiliki beberapa kendala, yaitu; 1) Ketergan tungan terhadap dana dalam melaksanakan tugas. Kegiatan yang bersifat kebencanaan belum bisa dilakukan rutin oleh KSB Pasie Nan Tigo. Hal ini disebabkan karena pelaksanaan kegiatan dianggap harus memiliki dana yang mencukupi baru bisa dijalankan. Akibatnya, apabila ada dana dari pemerintah yang turun, baru kegiatan yang berhubungan dengan kebencanaan dijalankan. Jika tidak, maka tidak akan ada kegiatan. Belum ada kegiatan rutin KSB yang berhubungan dengan kebencanaan. Biasanya KSB adalah relawan yang berasal dari masyarakat setempat.

2) Perlu peningkatan kapasitas anggota $K S B$. Perlu dilakukan peningkatan kapasitas para anggota KSB tersebut terhadap kemampuan dalam pengurangan resiko bencana. Ada lembaga lain yang sering datang untuk membahas mengenai kebencanaan adalah pihak kampus. Pada tahun 2019, kampus yang sudah melakukan kegiatan yang berhubungan pembe rian informasi tentang kebencanaan UMSB (Universitas Muhammadiyah Sumatera Barat) dan STKIP PGRI Sumbar. Kegiatan dilakukan di kantor Kelurahan Pasie Na Tigo. Biasanya dalam kegiatan ini, anggota KSB juga ikut dilibatkan. Berdasarkan informasi dari Seksi pencegahan BPBD Sumbar, sebenarnya setiap tahun BPBD Kota Padang memberikan pelatihan untuk anggot a KSB. Pelatihan ini diberikan sekali setahun.

\section{- Peran LSM dalam upaya pengurangan resiko bencana di Kelurahan Pasie Nan Tigo}

Selain itu, ada juga LSM yang pernah mendampingi di Kelurahan Pasie Nan Tigo. Ketika ditanya langsung ke masyarakat, mereka tidak mengetahui apa nama pasti dari LSM tersebut. Akan tetapi, pernah melakukan kegia tan seperti membagikan informasi mengenai bencana. Hal ini juga diperkuat oleh informasi dari seksi kebencanaan BPBD Sumbar, salah satu LSM yang melakukan kegiatan di Pasie Nan Tigo adalah LSM Kagami.

Pada Kelurahan Pasie Nan Tigo, tidak ada kebiasaan/adat istiadat/kearifan lokal dalam masyarakat yang berhubungan dengan bencana. Dahulu memang ada upacara tolak bala, akan tetapi hal tersebut tidak ditemukan lagi saat ini. Pada saat terjadi bencana gempa bumi, masyarakat akan berusaha mencari tempat yang lebih tinggi atau jauh dari pantai untuk menghindari kemungkinan gempa bumi yang berpotensi tsunami.

\subsection{Trust and Coorperative Norms}

a. Memiliki trust terhadap keluarga inti dan batih untuk memberikan bantuan saat pra dan saat terjadi bencana.

Dalam pengurangan resiko bencana dan pada saat terjadi bencana, keluarga dianggap sebagai tempat pertama untuk mengadu dan membantu. Baik itu bantuan secara moril atau materil. Trust terbentuk disebabkan adanya faktor kepercayaan karena hubungan keturunan/kekeluargaan.

\section{b. Kurangnya trust terhadap pemerin tah dalam upaya pengurangan resiko bencana.}

Masyarakat dalam hal ini memiliki kepercayaan terhadap pemerintah dalan mempersiapkan diri dalam menghadapi gempa bumi dan tsunami. Hal ini disebabkan karena adanya kegiatan simulasi dan pemberian informasi terhadap bencana yang dilakukan kepada masyarakat, serta adanya bantuan-bantuan bencana yang diberikan terhadap korban gempa seperti 2009 yang lalu. Akan tetapi, kepercayaan terhadap pemerintah tidak sepenuhnya, ada juga hal-hal yang disanksikan berdasarkan pengalaman yang sudah terjadi. Contohnya pada saat 2009, pemberian bantuan tidak merata terhadap masyarakat yang menjadi korban gempa. Selain itu, shelter yang resmi dari pemerintah belum dibangun di Kelurahan Pasie Nan Tigo. Sehingga ada kekhawatiran mengenai tempat evakuasi yang dituju ketika bencana gempa bumi dan tsunami terjadi.

\section{- Nilai gotong royong}

Kelompok rentan memiliki kepercayaan terhadap kemampuan masyarakat secara kolektif. Lagi, hal ini disampaikan berdasarkan pengalaman pada saat kejadian gempa. Masyarakat secara kolektif membantu membersihkan rumah ma syarakat yang rusak akibat gempa, apabila saat terjadi gempa maka ada yang mobilnya kosong akan memberikan tumpangan terhadap yang tidak punya kendaraan. Akan tetapi, ada juga yang tidak percaya terhadap kemampuan kolektif masyarakat karena dianggap menyelematkan diri sendiri terlebih dahulu lebih penting saat bencana dibandingkan harus membantu orang lain.

\section{Peluang dan Hambatan dalam Meman faatkan Modal Sosial}

Dalam melihat peluang dan hambatan, peneliti melakukan analisis SWOT terhadap modal sosial yang dimiliki. Analisis SWOT adalah metode perencanaan strategis yang digunakan untuk mengevaluasi kekuatan (strengths), kelemahan 
(weaknesses), peluang (opportunities), dan ancaman (threats). Berikut uraiannya:

1) Kekuatan (Strength) adalah kemampuan atau sumber daya yang dimiliki yang dapat dimanfaatkan demi keberhasilan.

a. Hubungan/interaksi dalam keluarga (nuclear familiy/extended family) intens dan bersifat asosiatif (kerjasama).

b. Memiliki keluarga yang dapat diandalkan memberikan bantuan secara moril/materil ketika menghadapi bencana.

c. Saling bertukar bantuan dan terlibat dalam kegiatan sosial dengan tetangga dan lingkungan sekitar baik yang berhubungan dengan pengurangan resiko bencana ataupun tidak.

d. Keterlibatan aktif secara sukarela dalam kegiatan sosial dan event

e. Dibentuknya KSB (Kelompok Siaga Bencana) yang bersifat sukarela dalam pengurangan resiko bencana

f. Memiliki trust terhadap keluarga inti dan batih.

g. Memiliki trust terhadap kemampuan ma syarakat secara kolektif

2) Kelemahan (Weaknesses) adalah kekurangan atau faktor penghambat yang ada di dalam

a. Hubungan/interaksi dengan teman dekat dan tetangga bersifat asosiatif dan disosiatif

b. Pemerintah baik dari tingkat kelurahan, kecamatan dan kota padang mengambil peran dalam pengurangan resiko ben cana akan tetapi belum maksimal.

c. Kurangnya trust terhadap pemerintah dalam upaya pengurangan resiko bencana.

d. Adanya kendala masyarakat berpar tisipasi dalam kegiatan pengurangan resiko bencana karena tidak bisa meninggalkan pekerjaan dan permasala han fisik (sakit-sakitan) apalagi bagi lansia.

3) Kesempatan (Opportunity) adalah faktor dari luar yang dapat dimanfaatkan demi keberhasilan

a. Peran LSM dalam upaya pengurangan resiko bencana di Kelurahan Pasie Nan Tigo

b. Peran PT dalam upaya pengurangan resiko bencana

4) Ancaman (Treats) adalah faktor dari luar juga yang mengancam keberhasilan dan tidak dapat diatasi dari dalam. a. Kelompok Siaga Bencana belum berdaya. Sehingga dalam melaksanakan tugas masih tergantung ada/tidaknya dana BPBD Kota Padang

b. Potensi adanya korban bencana gempa bumi dan tsunami masih tinggi karena belum adanya shelter yang memadai yang dibangun pemerintah.

c. Keluarga ada yang jaraknya berjauhan sehingga sulit memperoleh pertolongan langsung apabila terjadi bencana.

Walaupun Kota Padang merupakan daerah yang rawan bencana gempa bumi dan tsunami, akan tetapi masyarakat yang berada di zona merah enggan untuk pindah dan mencari rumah yang lebih aman bencana yang terletak di zona hijau. Hal ini dipengaruhi oleh beberapa hal seperti; 1) Sudah memiliki rumah dan aset milik sendiri di daerah zona merah; 2) Terikat dengan mata pencarian yang berada di zona merah; 3) Tidak memiliki cukup dana berlebih untuk pindah ke daerah yang lebih aman; 4) Pasrah dan percaya kehidupan dan kematian berada di tangan yang kuasa.

Ketika membahas mengenai peluang dalam pemanfaatan modal sosial, terbuka lebar untuk strategi memanfaatkan modal sosial yang dimiliki dalam pengurangan resiko bencana. Berikut uraian peluangnya pemanfaatannya:

1. Memperkuat ketahanan dan pemberdayaan keluarga dalam upaya pengurangan resiko bencana. Karena jika melihat kepada kekuatan yang dimiliki modal sosial, diketahui bahwa kelompok rentan memiliki interaksi yang intens dan asosiatif. Kelompok rentan menganggap keluarga yang dapat diandalkan ketika terjadi bencana. Hal ini memberikan peluang untuk melakukan memperkuat ketahanan dan memberdayakan keluarga sebagai upaya pengurangan resiko bencana. Sebelum memberdayakan pada tataran komunitas yang lebih besar, bisa dimulai dari tatanan keluarga terlebih dahulu.

2. Memberikan informasi dan simulasi mengenai kebencanaan di event-event kelurahan dan kegiatan sosial. Hal ini karna adanya keterlibatan aktif dalam kegiatan peringatan hari besar seperti kemerdekaan, adanya kelompok arisan, kelompok nelayan dan lain sebagainya. Dalam hal ini, perlu ditingkatkan keaktifan selain KSB, juga adanya dukungan pihak kelurahan dan kecamatan.

3. Memperkuat dan memberdayakan KSB. Selanjutnya KSB memperkuat komunitas. Langkah awal perlu adanya pemberdayaan anggota KSB sehingga kegiatan pengurangan resiko bencana bisa berjalan karena kesadaran masyarakat bahwa pentingnya pengurangan resiko bencana dilakukan.

4. Memanfaatkan LSM dan PT untuk penguatan komunitas dan pemberdayaan. 
Adapun strategi dalam menghadapi tantangan dalam pemanfaatan modal sosial adalah sebagai berikut:

1. Meningkatkan kapasitas KSB (Kelompok Siaga Bencana) yang bersifat sukarela dalam pengurangan resiko bencana. KSB dalam melaksanakan tugasnya tergantung dana. Sehingga apabila tidak ada dana, tidak bisa melakukan pekerjaan. Hal perlu dilakukan adalah meningkatkan kesadaran bahwa pengurangan resiko bencana ini adalah kebutuhan bersama, sehingga tidak perlu menunggu terlebih dahulu dana baru dilaksanakan.

2. Keterlibatan lansia dalam pengurangan resiko bencana karena lansia sering tidak terlibat karena permasalahan fisik yang tidak memungkinkan untuk hadir dalam kegiatan pemberian informasi ataupun simulasi.

3. Membangun kesadaran bahwa pengu rangan resiko bencana adalah tanggung jawab bersama. Salah satunya dengan mencari alternatif shelter sementara di Kelurahan Pasie Nan Tigo atau mewakafkan tanah yang bisa dijadikan tempat untuk membangun shelter.

\section{KESIMPULAN}

$\mathrm{D}$ ari hasil penelitian, maka dapat disim pulkan bahwa kelompok rentan pada Kelurahan Pasie Nan Tigo sudah memiliki modal sosial dari 4 apek yaitu; 1) Personal relationship, seperti adanya hubungan/ interaksi keluarga (baik itu nuclear family dan extended family) yang bersifat asosiatif, sedangkan interaksi dengan teman dekat/ tetangga bersifat asosiatif dan disosiatif; 2) Social network support, seperti memiliki keluarga yang bias diandalkan dalam memberi bantuan moril dan materil, saling bertukar bantuan dan terlibat dalam kegiatan sosial dengan tetangga dan lingkungan sekitar baik yang berhubungan dengan pengurangan resiko bencana ataupun tidak, serta pemerintah baik dari tingkat kelurahan, kecamatan dan Kota Padang mengambil peran dalam pengurangan resiko bencana akan tetapi belum maksimal; 3) Civic engangement, seperti keterlibatan aktif secara sukarela dalam kegiatan sosial dan event, dibentuknya KSB (Kelompok Siaga Bencana) yang bersifat sukarela, dan adanya peran LSM dalam upaya pengurangan resiko bencana; 4) Trust and cooperative norm, seperti memiliki trust terhadap keluarga inti dan batih untuk mem berikan bantuan saat pra dan saat terjadi bencana, kurangnya trust terhadap pemerintah dalam upaya pengurangan resiko bencana, dan adanya nilai gotongroyong. Selain itu, dalam memanfaatkan modal sosial terdapat peluang dan tantangan. Baik secara internal ataupun secara eksternal. Oleh karena itu, diperlukan berbagai macam strategi dalam memanfaatkan peluang dan menghadapi tantangan dalam memanfaatkan modal sosial pada kelompok rentan. Sehingga upaya pengurangan resiko bencana dapat dilakukan dengan maksimal.

\section{E. UCAPAN TERIMAKASIH}

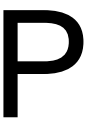
enulis mengucapkan terimakasih kepada informan yang telah meluangkan waktunya dalam penelitian ini. Selain itu, penulis juga mengucapkan terimakasih kepada semua pihak yang telah memberikan dukungan baik moril ataupun materil terhadap terbitnya artikel ini.

\section{DAFTAR PUSTAKA}

Afrizal. (2014). Metode Penelitian Kualitatif. Jakarta: PT RajaGrafindo Persada Amri, Robi. Muhammad dkk. (2016). Risiko Bencana Indonesia. Jakarta: BNPB

Anwar, Herryal Z. (2012). Kerentanan dan Kapasitas Respon Masyarakat Kota Padang terhadap Bencana Tsunami. Jurnal Riset Geologi dan Pertambangan Vol 22 No. 1 tahun 2012

Azwar. (2019). Walfare State Policy Model as Poverty Reduction Strategy in the West Sumatera Districts and and Cities. Jurnal Antropologi: Isu-isu Sosial Budaya Vol 21 No 2 Tahun 2019 (hal 233)

Desiyanti, Armalia. (2018). Statistik Daerah Kota Padang. Padang: BPS Kota Padang

Febriana. (2015). Kesiapsiagaan Masyarakat Desa Siaga Bencana dalam Menghadapi Gempa Bumi di Kecamatan Meuraxa Kota Banda Aceh. Jurnal Ilmu Kebencanaan (JIKA) Vol 2 No 3 Agustus 2015 (hal 41-49)

Fitri, Wanda. (2014). Nilai Budaya Lokal, Resiliensi, dan Kesiapan Menghadapi Bencana Alam. Personifikasi Vol 5 No 2 November 2014 (hal 133-135)

Harli, Yomal. (2015). Tingkat Kerentanan Sosial Masyarakat Kota Padang di Wilayah Rawan Tsunami dengan Analisis Sistem Informasi Geografis (GIS). Padang: Tesis Jurusan Teknik Sipil Program Pascasarjana Bung Hatta.

L Zamzami et al. (2020). 'Socio-Cultural Impacts Of Marine Conservation Areas In Indonesian Fishing Communities'. IOP Conf. Ser.: Earth Environ. Sci. 430012016

Motkuri, Venkatanarayana.(2018). Some Notes on the Concept of Social Capital: A Review of Perspectives, Definitions, and Measurement. MPRA Paper No.86362, 25 April 2018 
Purbasari, Verbena Ayu Ningsih dan Sunarto. (2019). Interaksi Sosial Etnis Cina-Jawa Kota Surakarta. Jurnal Antropologi: Isu-isu Sosial Budaya Vol 21 No 1 Tahun 2019 (hal 5)

Putri, Siska Elasta. (2018). Pemetaan Jaringan Sosial dalam Organisasi: Studi pada Distributor Tupperware Unit Simabur Indah di Batusangkar Sumatera Barat. Jurnal Antropologi: Isu-isu Sosial Budaya Vol 20 No 2 Tahun 2018 (hal 141)

Sitorus, Purnama Betty Rosalina. (2018). Budaya Kerentanan dan Kapasitas Masyarakat Kepulauan Mentawai Menghadapi Bencana Gempa Bumi dan Tsunami. Jurnal Vokasi Indonesia Volume 16 No 2 Tahun 2018 (hal 30)

Tanzil dkk. (2019). Modal Sosial dan Mitigasi Bencana pada Masyarakat Pulau Makasar Kota Baubau. Talenta Conference Series: Local Wisdom Social and Arts Volume 2 Issue 3 Tahun 2019

Teja, Mohammad. (2018). Kesiapsiagaan Masyarakat terhadap Kelompok Rentan dalam Menghadapi Bencana Alam di Lombok. Info SINGKAT (Kajian Singkat terhadap Isu Aktual dan Strategis) Vol X. No 17/ Puslit/ September/2018 (Hal 13-18)

UNDP. (2012). Panduan: Pengurangan Resiko Bencana Berbasis Komunitas

Verayanti, Lany. (2013). Pemanfaatan Modal Sosial sebagai Strategi Masyarakat dalam Mengatasi Dampak dan Upaya Menurunkan Tingkat Resiko Bencana. Studi Kasus: Nagari Batu Kalang Kecamatan Padang Sago Kabupaten Padang Pariaman Provinsi Sumatera Barat. Padang: Tesis Jurusan Sosiologi FISIP Universitas Andalas.

Yunarti, Tatik. (2018). Kepemimpinan dan Pengelolaan Modal Sosial dalam Penanggulangan Bencana Banjir. Jurnal Makna Volume 3 No 1 Maret 2018 (hal 126). 